\title{
THE THIRTEENTH ANNUAL INTERAGENCY GEOTHERMAL COORDINATING COUNCIL REPORT FOR FISCAL YEAR 1988
}

MARCH 21, 1989

Prepared by the:

Budget and Planning Working Group of the Interagency Geothermal Coordinating Council 


\section{DISCLAIMER}

This report was prepared as an account of work sponsored by an agency of the United States Government. Neither the United States Government nor any agency Thereof, nor any of their employees, makes any warranty, express or implied, or assumes any legal liability or responsibility for the accuracy, completeness, or usefulness of any information, apparatus, product, or process disclosed, or represents that its use would not infringe privately owned rights. Reference herein to any specific commercial product, process, or service by trade name, trademark, manufacturer, or otherwise does not necessarily constitute or imply its endorsement, recommendation, or favoring by the United States Government or any agency thereof. The views and opinions of authors expressed herein do not necessarily state or reflect those of the United States Government or any agency thereof. 


\section{DISCLAIMER}

Portions of this document may be illegible in electronic image products. Images are produced from the best available original document. 


\title{
THE THIRTEENTH ANNUAL INTERAGENCY GEOTHERMAL COORDINATING COUNCIL REPORT FOR
}

\author{
FISCAL YEAR 1988
}

MARCH 21, 1989

\author{
PREPAREd BY THE: \\ Budget and Planning Working Group \\ OF THE
InTERAGENCY GeOtheRMAL COORDINATING COUNCIL
}


I. INTRODUCTION.......................................... 1

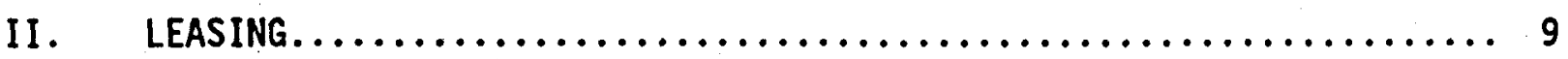

Competitive Leasing.................................. 10

Non-Competitive Leasing............................... 10

Utilization......................................... 10

III. HYDROTHERMAL RESOURCE ASSESSMENT, AND EXPLORATION............. 11

IV. GEOTHERMAL ENERGY R\&D PROGRAM............................. 13

Hydrothermal Research............................... 13

Geopressured-Geothermal Research......................... 15

Hot Dry Rock Research................................... 16

Magma Research......................................... 16

Basic Geosciences Research........................... 17

V. ENVIRONMENT $. \ldots \ldots \ldots \ldots \ldots \ldots \ldots \ldots \ldots \ldots \ldots \ldots \ldots \ldots \ldots \ldots \ldots \ldots, 18$

VI. TECHNOLOGY TRANSFER................................ 20

VII. FEDERAL USE OF GEOTHERMAL ENERGY......................... 22

VIII. PRIVATE SECTOR USE OF GEOTHERMAL ENERGY.................... 23

,

\section{LIST OF FIGURES AND TABLES}

Figure 1. IGCC Memeber Agencies.............................. 3

Table 1. Significant Events in the Development of Geothermal Energy in the United States..................................... 4

Table 2. Federal Funding for Geothermal Energy................... 8

Table 3. Geothermal Resources Development Fund and Guaranty Authority... 21

Table 4. Qualification Status of Non-Utility Geothermal Generating Capacity 


\section{INTRODUCTION}

Geothermal energy is the natural heat of earth, and can be tapped as a clean, safe, and economical alternative source of energy. Three types of geothermal resources (hydrothermal, geopressured, and hot dry rock) are expected to be commercially exploited by the year 2000. A fourth type, magma, may be economic in the next century. Only hydrothermal resources, which are underground accumulations of hot water or steam, are technically and economically feasible for exploitation at this time. The highest quality hydrothermal resources are being tapped now, and much more of this energy resource is recoverable with current or near-current technology. Therefore, those resources could make a significant contribution, both to increasing domestic energy supplies and to reducing the United States' dependence on imported oil. Moreover, they can be used for various purposes: electric power production, residential and commercial space heating and cooling, industrial process heat, and agricultural process applications.

The geothermal industry currently has more than 2,575 MWe of baseload electric energy production either on line or under construction (equivalent to two and one-half nuclear power plants) at prices competitive with coal and nuclear power. Additionally, the industry produced nearly 17,000 billion BTU's of heat energy for direct use last year. Based on a 1987 Electric Power Research Institute (EPRI) survey of industry plans, the U.S. hydrothermal electric power capacity may reach 5,316 MWe by the year 2000 (1987 EPRI-Survey of Geothermal Electric Utilities). Thus, geothermal will play an increasingly important role in the U.S. energy future.

The federal government has been actively involved in the development of geothermal energy since 1970, when the Geothermal Steam Act was passed. It has been engaged in the leasing of federal lands for geothermal exploration and development, and conducts numerous research, development, and demonstration programs to investigate the use of geothermal energy. This report summarizes the accomplishments of the federal government during fiscal year 1988 , and describes federal geothermal energy programs. Table 1 (pp. 4-7) presents a chronological history of significant, domestic geothermal energy developments.

The objective of the federal geothermal energy activities is twofold: 1) to provide the hydrothermal industry with near-term support to improve the feasibility and economics of geothermal development for reservoirs of lower quality; and 2) to undertake long-term, high-risk research to develop a technology base for the advanced forms of geothermal energy. This strategy will permit industry to make informed investment decisions in response to the demands of the energy market. Private industry's leading role is the direct planning, financing, and constructing of demonstration and commercial geothermal energy systems. 
The efficient and timely development of geothermal resources depends on the coordinated efforts of federal, state, and local governments; industry, consumer, and environmental groups; and private citizens. The Interagency Geothermal Coordinating Council (IGCC) was established in accordance with the provisions and intent of Public Law 93-410, the Geothermal Energy Research, Development and Demonstration Act of 1974, as amended by Public Law 95-238, and Public Law 95-91, the Department of Energy Organization Act. Council membership is composed of an assistant secretary from the Departments of Energy (DOE), Interior (DOI), Treasury, Agriculture, Defense (DOD), Commerce, and Housing and Urban Development, and the assistant administrator from the Environmental Protection Agency (EPA). The assistant secretary from the Department of Energy, currently the Assistant Secretary, Conservation and Renewable Energy, is Council Chairperson. A membership organizational chart is shown in Figure 1 .

The Council's objective is to coordinate a national geothermal energy research, development and demonstration program and to serve as a forum for discussion of those federal plans, activities, and policies which are related to or impact geothermal energy, including ancillary activities of agencies not represented by Council membership. Such other agencies may be represented as appropriate on working groups and panels assigned the responsibility for specific efforts on problems, policies, or programs in which those agencies are involved or have an interest. The Council, through the Chairperson, may make recommendations to the appropriate agencies and the President with regard to alternative policies or actions considered necessary or desirable to expedite research and development of technologies leading to the development and utilization of geothermal energy resources. The federal geothermal activities budget of the member agencies is presented in Table 2.

The provisions of section 302 of Public Law 93-410, require that the Council must prepare and submit to the President and Congress by June 30 of each year a report on federal activities and programs in geothermal energy. This report summarizes the geothermal energy progress for fiscal year 1988. 
Figure 1

\section{IGCC MEMBER AGENCIES}

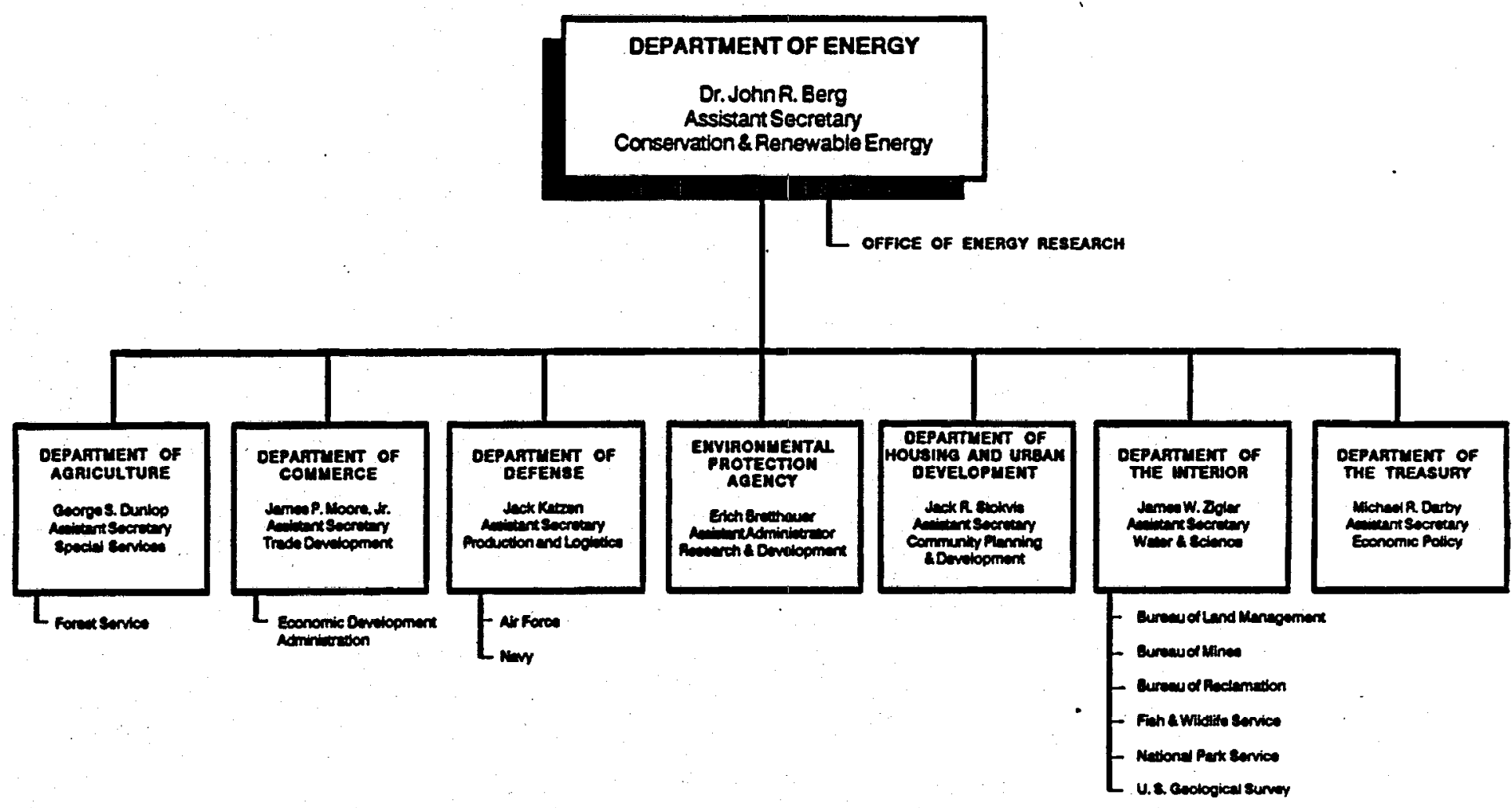


TABLE 1

SIGNIFICANT EVENTS IN THE DEVELOPMENT

OF GEOTHERMAL ENERGY IN THE UNITED STATES

1884 - District heating implemented in Boise, Idaho

1900 - Hot water provided in homes in $\mathrm{Klamath}$ Falls, Oregon

1916 - Power generation at The Geysers resort

1927 - First exploratory geothermal wells drilled in Imperial Valley, California by Pioneer Development Company

1959 - Small pilot plant operated near Niland, California on Sinclair No. 1 well

1960 - Commercial electricity generated from dry steam at The Geysers, California

1970 - Geothermal Steam Act passed (Public Law 91-581)

1973 - NSF became lead agency for Federal Geothermal Programs

- USGS, AEC, NSF prepared the first Federal Geothermal Program Plan

1974 - Geothermal Energy RD\&D Act (Public Law 93-410) passed which included the establishment of the Geothermal Loan Guaranty Program (GLGP)

1975 - ERDA formed; Division of Geothermal Energy (DGE) formed primarily from NSF and AEC staff to manage an RD\&D program

- USGS released first national geothermal resource estimates and inventory

1977 - Issued the first loan guaranty to Republic Geothermal, Inc. for field development at East Mesa, California

- DOE formed; DGE continued to manage the RD\&D program

- Bureau of Reclamation successfully completed desalting tests to produce fresh water from geothermal brines

1978 - Energy Tax Act (Public Law 95-618) passed

- Public Utility Regulatory Policies Act (Public Law 95-617) enacted. EPA issued pollution control guidel ines for geothermal energy development

- Successful hot dry rock experiment conducted in New Mexico

- First geothermal crop-drying plant built in Nevada 


\section{TABLE 1 (Continued)}

SIGNIFICANT EVENTS IN THE DEVELOPMENT

OF GEOTHERMAL ENERGY IN THE UNITED STATES

1979 - USGS released updated national geothermal resource estimates and inventory

- Streaml ining task force recommended measures to IGCC to speed federal leasing

- U.S. Navy awarded a contract to develop 75 MWe at the Coso KGRA on the Naval Weapons Center, China Lake, California

- First geothermal electricity produced from federal lands, at The Geysers, California

- World's first experimental binary-cycle plant (10 MWe) built by industry at East Mesa, California

1980 - FERC issued regulations (18 CFR 292) establishing hydrothermal geothermal resources as renewable resources and geothermal facilities as qualifying facilities

- World's largest single geothermal power unit (132 MWe) generated electricity at The Geysers, California

- 10 MWe flash-steam plant built by industry at Brawley, California

- First electric power from a hot dry rock resource produced at Fenton Hill, New Mexico

- First geothermal ethanol plant began production at La Grande, Oregon under private funding

- First five DOE-sponsored field demonstrations of direct heat applications became operational

- First deep geothermal reservoir confirmation well drilled in Atlantic Coastal Plain near Crisfield, Maryland

- Crude 0il Windfall Profits Tax Act (Public Law 96-223) passed, providing tax credit increase for geothermal equipment

- Energy Security Act (Public Law 96-294), containing Title VI, "The Geothermal Energy Act of 1979," passed

1981 - First U.S. geothermal electric generation plant outside the 48 contiguous states brought on- 1 ine in the Puna resource area in Hawati 
TABLE 1 (Continued)

SIGNIFICANT EVENTS IN THE DEVELOPMENT

OF GEOTHEPMAL EMERGY IN THE UNITED STATES

1981 - The Insurance Company of North America began offering insurance against the financial risk of reservoir failure

- The practical demonstration of generating electricity from moderate-temperature geothermal fluids was accomplished at Raft River, Idaho

- A mobile well-head generator with a net output of 1.6 MWe was installed at Roosevelt Hot Springs, Utah

- USGS research drilling at Newberry Volcano, Oregon indicated for the first time that temperatures $\left(265^{\circ} \mathrm{C}\right.$ at $\left.3,057 \mathrm{ft}\right)$ sufficient for electrical production existed in the Cascade Range

- FERC issued amendments to its regulations for qualifying small power production facilities incorporating the provisions of the Energy Security Act relating to non-utility geothermal facilities

1982 - A 10 MWe flash plant utflizing hypersaline brine began operation at the Salton Sea KGRA, California

- An 80 MWe geothermal electric power plant to be constructed by Occidental Geothermal, Inc. in Lake County, California and a 49 MWe geothermal electric power plant to be constructed by Republic Geothermal, Inc. and the Parsons Corporation in the Imperial Valley, California were certified by the FERC as qualifying facilities. Magma Power Company and Magma Development Corporation issued a public notice of self-qualification for an existing 11 MWe geothermal power plant located in East Mesa, California

- In an effort by DOI to accelerate the geothermal leasing program, a record 16 competitive lease sales were held in which 578,656 acres were offered

- USGS completed the first quantitative national assessment of lowtemperature $\left(<90^{\circ} \mathrm{C}\right)$ geothermal resources of the United States

1983 - Federal leasing regulations were rewritten, resulting in the deletion of burdensome, counterproductive requirements

1984 - The first commercial electrical power from federal lands outside California was generated, with 20 MWe brought on-line by Phillips Geothermal in the Roosevelt Hot Springs KGRA in Utah

1985 - Lease acreage 1 imit increased by DOI from 20,480 to 51,200 acres per state 
TABLE 1 (Continued)

SIGNIFICANT EVENTS IN THE DEVELOPMENT

OF GEOTHERMAL ENERGY IN THE UNITED STATES

1986 - The Salton Sea scientific well was drilled and cored to $10,564 \mathrm{ft}$; cuttings, fluid samples and geophysical well logs were obtained, and preliminary flow tests conducted

- Congress acted to preclude geothermal leasing where, in the judgment of the Secretary of the Interior, development would result in significant adverse effects to significant thermal features in national parks.

1987 - DOE cost-shared with industry the drilling of three deep thermal gradient test wells within the Cascades volcanic area of the Pacific Northwest -- which demonstrates the utility of this technique in identifying underlying hydrothermal features such as those beneath the Cascades

- Navy Geothermal Plant Number One, Unit Number One, at Naval Weapons Center, China Lake, California, began delivering power to the public utility grid. Unit One is rated at 25-megawatts capacity. NWC's peak power demand is 20 megawatts. Negotiations are underway for an additional 135 megawatts at planned Units Two through Six

1988 - Geothermal Steam Act Amendments of 1988 were signed into law (Public Law 100-443). This law significantly modifies the geothermal leasing program by providing two 5 -year extensions of the primary term of a geothermal lease if geothermal steam has not been produced in commercial quantities by the end of the primary term. The Act further provides protection for significant thermal features in units of the National Park System from the effects of geothermal development.

- Navy Geothermal Plant Number One, Unit Number One, at Naval Weapons Center, China Lake, California is running steadily at 34 MWe. Plant Number One, Units Two and Three, are under construction. Completion date is set for December 1988. Units One through Three will bring the Navy's operating capacity to 80 MWe. Permitting is underway for an additional 80 MWe with planned Units Four through Six, with an expected start-up in late 1989. 
TABLE 3
FEDERAL FUNDING FOR GEOTHERHAL ENERGY $(\$ 1000)$ (a)

\begin{tabular}{|c|c|c|c|c|c|c|c|c|c|c|c|c|}
\hline ORGAMIZATION UNIT & $\begin{array}{r}\text { Actual } \\
1979\end{array}$ & $\begin{array}{r}\text { Actual } \\
1980\end{array}$ & $\begin{array}{r}\text { Actual } \\
1981\end{array}$ & $\begin{array}{r}\text { Actual } \\
1982\end{array}$ & $\begin{array}{r}\text { Actual } \\
1983\end{array}$ & $\begin{array}{r}\text { Actual } \\
1984\end{array}$ & $\begin{array}{r}\text { Actual } \\
1985\end{array}$ & $\begin{array}{r}\text { Actual } \\
1986\end{array}$ & $\begin{array}{r}\text { Actual } \\
1987\end{array}$ & $\begin{array}{r}\text { Actual } \\
1988\end{array}$ & $\begin{array}{r}\text { Est imated } \\
1989\end{array}$ & $\begin{array}{r}\text { Requested } \\
1990\end{array}$ \\
\hline $\begin{array}{l}\text { Department of Agriculture } \\
\text { U.S. Forest Service }\end{array}$ & 780 & 750 & 700 & 600 & 500 & 525 & 946 & 1,081 & 966 & 900 & 900 & 900 \\
\hline $\begin{array}{l}\text { Department of Defense } \\
\text { Mavy } \\
\text { Air Force }\end{array}$ & $\begin{array}{r}300 \\
0\end{array}$ & $\begin{array}{l}230 \\
200\end{array}$ & $\begin{array}{r}930 \\
1,010\end{array}$ & $\begin{array}{l}848 \\
182\end{array}$ & $\begin{array}{r}863 \\
0\end{array}$ & $\begin{array}{r}1,100 \\
0\end{array}$ & $\begin{array}{r}1,260 \\
0\end{array}$ & $\begin{array}{r}1,380 \\
0\end{array}$ & $\begin{array}{r}621 \\
0\end{array}$ & $\begin{array}{r}440 \\
0\end{array}$ & $\begin{array}{r}697 \\
0\end{array}$ & $\begin{array}{r}550 \\
0\end{array}$ \\
\hline Doo Total & 300 & 430 & 1.940 & 1.030 & 863 & 1.100 & 1.260 & 1,380 & 621 & 440 & 697 & 550 \\
\hline $\begin{array}{l}\text { Department of Energy } \\
\text { Conservat Ion \& Renewable } \\
\text { Energy } \\
\text { Office of Energy } \\
\text { Research (b) } \\
\text { Environment } \\
\text { GLGP (Program Direct ion) }\end{array}$ & $\begin{array}{r}152.990 \\
2,100 \\
2.820 \\
0\end{array}$ & $\begin{array}{r}3.102 \\
1.950 \\
181\end{array}$ & $\begin{array}{r}142,521 \\
3,305 \\
723 \\
193\end{array}$ & $\begin{array}{r}43.713 \\
2.650 \\
0 \\
134\end{array}$ & $\begin{array}{r}79,939 \\
2,500 \\
0 \\
120\end{array}$ & $\begin{array}{r}32.615 \\
2,400 \\
0 \\
101\end{array}$ & $\begin{array}{r}33,511 \\
2.600 \\
0 \\
121\end{array}$ & $\begin{array}{r}25.200 \\
2.800 \\
0 \\
72\end{array}$ & $\begin{array}{r}20.630 \\
2.930 \\
0 \\
72\end{array}$ & $\begin{array}{r}20.725 \\
3.000 \\
0 \\
100\end{array}$ & $\begin{array}{r}19,556 \\
2.700 \\
0 \\
100\end{array}$ & $\begin{array}{r}17.024 \\
2.000 \\
0 \\
100\end{array}$ \\
\hline DOE Total & 157.910 & 155,103 & 146,742 & 46.497 & 82.559 & 35,116 & 36,232 & 28,072 & 23,632 & 23,825 & 22.356 & 19.121 \\
\hline $\begin{array}{l}\text { Department of Interior } \\
\text { Mat Ional Park Service } \\
\text { Fish \& Wildilife Service } \\
\text { Bureau of Land Mngt. } \\
\text { Bureau of Rec lanation } \\
\text { Bureau of Mines } \\
\text { USGS. Geothermal } \\
\text { Research Program }\end{array}$ & $\begin{array}{r}(c) \\
200 \\
3.340 \\
550 \\
1.050 \\
\vdots 12.043\end{array}$ & $\begin{array}{r}(c) \\
200 \\
3.410 \\
910 \\
800\end{array}$ & $\begin{array}{r}(c) \\
70 \\
3,548 \\
60 \\
400 \\
7,889\end{array}$ & $\begin{array}{r}100 \\
100 \\
4.055 \\
60 \\
384 \\
\\
7.953\end{array}$ & $\begin{array}{r}50 \\
50 \\
3,861 \\
30 \\
300 \\
7,090\end{array}$ & $\begin{array}{r}250 \\
0 \\
3.197 \\
0 \\
0 \\
7.215\end{array}$ & $\begin{array}{r}250 \\
0 \\
3.227 \\
0 \\
0 \\
7.314\end{array}$ & $\begin{array}{r}250 \\
0 \\
2,639 \\
0 \\
0 \\
5,601\end{array}$ & $\begin{array}{r}225 \\
0 \\
2,475 \\
0 \\
0 \\
5,841\end{array}$ & $\begin{array}{r}400 \\
0 \\
2.200 \\
0 \\
0 \\
5.943\end{array}$ & $\begin{array}{r}1.000 \\
0 \\
2,500 \\
0 \\
-\quad 0 \\
5.909\end{array}$ & $\begin{array}{r}1.000 \\
0 \\
1.613 \\
0 \\
0 \\
4.928\end{array}$ \\
\hline DoI Total & 17.183 & 15.367 & 11.967 & 12.652 & 11,381 & 10,662 & 10,791 & 8,490 & 8.541 & 8.543 & 9.409 & 7,541 \\
\hline $\begin{array}{l}\text { Environmental Protection } \\
\text { Agency }\end{array}$ & 920 & 850 & 1.550 & (d) & (d) & (d) & (d) & (d) & (d) & (d) & (d) & (d) \\
\hline $\begin{array}{l}\text { TOTAL FEDERAL GEOTHERMAL } \\
\text { PROGRAM BUDGET }\end{array}$ & 177.093 & 172.500 & 162,899 & 60.779 & 95,303 & 47.403 & 49.229 & 39.023 & 33.760 & 33.708 & 33.362 & 28.115 \\
\hline
\end{tabular}

(a) Budget authority rounded to nearest thousand.

(b) Best estimate based on the portion of Basic Energy Sciences research related to geothermal act ivities.

The est imate represents the applicable portions of a number of research tasks.

(c) Mot avallable.

(d) While the EPA budget since 1982 has not targeted resources specifically for geothermal, other

RAD at EPA (0.g.. disposal of Ilquid effluents) or programmat ic act ivities (e.g. . permitting assistance to states) may be applicable to geothermal energy. 


\section{LEASING}

The goal of the federal geothermal leasing program is to make federal lands available to industry for exploration and development in an environmentally acceptable way. Leasing is administered by the Bureau of Land Management (BLM), with the consent of the Forest Service (FS) where National Forest System lands are involved. In addition, BLM and FS must consult with the U.S. Geological Survey (USGS) and the National Park Service (NPS) whenever federal 1 ands offered for leasing are located adjacent to units of the National Park System 1isted under Public Law 100-443 as containing significant thermal features.

In December 1987, the BLM, FS, USGS, and NPS signed an Interagency Agreement (IA) to implement the leasing procedures required under Section 115 of the Department of the Interior and Related Agencies Appropriations Act for FY 1987 (Public Law 99-591). The specific requirements of this Act were reported extensively in the Twelfth Annual Interagency Coordinating Council Report for FY 1987. Many of the leasing procedures and provisions of Section 115 were incorporated into the Geothermal Steam Act Amendments of 1988 which were signed into law on September 22, 1988, as Public Law 100-443. This IA remains in effect because the leasing procedures outlined in the IA remain appropriate and applicable to leasing decisions necessitated under the Geothermal Steam Act Amendments.

The Geothermal Steam Act Amendments of 1988 provide new opportunities for extension of qualified leases for up to 10 years beyond their primary terms. The lessees must demonstrate bona fide efforts to produce or utilize geothermal resources and agree to either make payments in lieu of commercial quantities production or make significant expenditures during the periods of lease extension. The Act also added new types of lands to those closed to leasing and allows wells capable of production, but not actually producing, to continue in effect for as long as lessees make diligent efforts to commence production. It further provides protection for significant thermal features in the 16 iisted units of the National Park System from the effects of geothermal development.

Section 6 requires the Secretary of the Interior to maintain a 1 ist of significant thermal features and adds Crater Lake National Park, Big Bend National Park, and Lake Mead National Recreation Area to the 1ist of features previously listed by the Department in June 1987. This section allows the Secretary to add to the list of units. The NPS, in cooperation with USGS, is required to establish a research program on the geothermal resources in 1 isted units and assess data for these features near current or proposed geothermal development areas. Paragraph (c) further requires the Secretary to attach specific stipulations to all permits issued, extended, renewed, or modified where it is determined that development could result in an adverse effect to a listed feature.

Section 6 has two other provisions related to the consideration of park resources in the geothermal leasing program. One is the requirement on the Secretary of Agriculture to consider the effects on significant thermal features in units of the National Park System when determining whether to consent to leasing on lands in the National Forest System. Another is the 
continued prohibition of leasing federal lands in the Island Park Geothermal Area.

Section 7 requires the Secretary of the Interior to submit to Congress a report on the presence or absence of significant thermal features in Crater Lake National Park. This report is due by March 22, 1989.

Because of the concern over existing geothermal development outside of Yellowstone National Park, section 8 of the Act provides for a study of the impact of the present and potential geothermal development in the corwin Springs KGRA on the thermal features in the park. Production from existing wells and any development of new wells is prohibited until six months after the report is received by Congress.

Rulemaking to implement the Act is underway and expected to be final in the first quarter of 1989.

\section{COMPETITIVE LEASING}

At the end of FY 1988, there were 233 competitive leases in effect on a total of 406,355 acres (Cal ifornia, 140 leases on 232,662 acres; Nevada, 66 leases on 122,393 acres; Oregon/Washington, 8 leases on 16;825 acres, and Utah with 19 leases on 34,475 acres).

\section{NON-COMPETITIVE LEASING}

At the end of FY 1988, there were 531 non-competitive leases in effect on a total of 939,575 acres (Cal ifornia, 128 leases on 181,569 acres; Nevada, 160 leases on 262,672 acres; Oregon/Hashington, 225 leases on 463,060 acres; and Utah, 18 leases on 32,274 acres). million.

The revenues generated by leasing on Federal land has amounted to over $\$ 18$

\section{UTILIZATION}

At the end of FY 1988, 725 MWe of capacity were on-line from federal leases at The Geysers (Cal ifornia); 70 MWe from East Mesa (California); 62.5 MWe from Dixie Valley (Nevada); 20 MWe from Rooseve1t Hot Springs (Utah); 16 MWe from Beowawe (Nevada); 15 MWe from Steamboat Springs (Nevada); 10 MWe from Desert Peak (Nevada); 9.8 MWe from San Emidio (Nevada); 3.6 MWe from Soda Lake (Nevada); and 2.2 MWe from Cove Fort (Utah) for a total of 934.1 MWe. 


\section{HYDROTHERMAL RESOURCE IDENTIFICATION, ASSESSMENT, AND EXPLORATION}

The DOE and the USGS have several programs designed to evaluate the geothermal energy potential in the United States. These programs are complementary in nature, focusing on different aspects of this goal. USGS activities emphasize geothermal resource inventory and assessment work; DOE activities focus on the technologies for more detailed study of specific resource areas. The main objectives of the USGS programs are to: (1) characterize the geological, hydrological, geochemical, and geophysical nature of the various types of geothermal resources; (2) estimate the location, distribution, and energy content of both the presently identified and the undiscovered geothermal resources of the U.S.; (3) develop resource assessment technology; (4) conduct regional resource assessments and national resource inventories; and (5) contribute to the confirmation of selected specific geothermal reservoirs. The programs al so address geoenvironmental effects and issues dealing with the longevity of geothermal systems.

Major accomplishments of the U.S. Geological Survey's Geothermal Research Program in FY 1988 were:

- Preparation of new geologic maps of the Long Valley/Mono Craters area, California; Medicine Lake Volcano, California; the San Francisco volcanic field, Arizona; and the island of Hawaii. Such maps, representing tens of man-years of work, are fundamental in defining the size, geometry, and likely state of magmatic heat sources, and the potential for their interaction with groundwater.

- Completion of interrelated research projects on the geology, geophysics, and geochemistry of Newberry caldera, Oregon and its hydrothermal system.

- Seismic imaging that defined a large body of low-velocity material beneath Medicine Lake Volcano, probably magma or partially-molten rock.

- Evaluation of geophysical and geochemical data from drill holes and hot springs in central Oregon. High-measured heat flow along the western edge of the High Cascades apparently results from subsurface flow of thermal water from heat sources to the east, rather than from a large shallow magma chamber beneath the western edge of the High Cascades.

- Magnetotelluric soundings and telluric profiles around the Breitenbush Hot Springs area, Oregon, for interpretation of tectonic structures and flow of hot groundwater. 
- Development of a new tectonic interpretation of segmented subduction beneath the Cascades, and overlap of the Cascades with westwardmigrating volcanism of the Basin and Range province. Areas of. overlap may hold geothermal resources that are not associated with large stratovolcanoes.

- Acquisition of important geochemical data from new wells in Long Valley, California. The new data will help in constructing an improved model of that hydrothermal system. The data are consistent with previous models of water being heated in the western part of the caldera and which flow east, in contrast. to a previous interpretation from helium isotope ratios that magma lies beneath the eastern part of the caldera.

- Analyses of fluid and gas samples from the deep Cajon Pass well to learn the extent of fracture permeability in that fault environment and its implications for geothermal fields in similar tectonic settings.

- Reconnaissance geologic and dating studies of the Emmons Lake caldera complex and Mt. Spurr, Alaska.

- Reconnaissance geologic investigations and studies of hydrothermal alteration in the Katmai area, Alaska, to support site selection for a multi-agency (NSF-DOE-USGS) investigation of the magma body beneath Katmai Volcano.

- Refinement of aeromagnetic methods for estimating the depth of Curietemperature isotherm (the depth at which rocks are hot enough to lose their magnetization). The new methods have been applied in the Basin and Range province of Nevada, to evaluate both known and suspected geothermal areas.

- Analysis of borehole physical and chemical data from the joint NSFDOE-USGS Salton Sea (California) Scientific Drilling Program well. The Salton Sea data reveal a correlation between several borehole geophysical measurements and the degree of core alteration. The relation should permit rapid estimation of the alteration and, consequently, the conditions within the Salton Sea hydrothermal system.

- Fundamental research on thermodynamic properties, electronic structure, microstructures, reaction kinetics, and phase equilibria of minerals for use of minerals as geothermometers and geobarometers.

- Technical assistance to several foreign countries (Mexico, Costa Rica, Honduras, Panama, Kenya, and the Azores) on studies of geothermal fields. 


\section{GEOTHERMAL ENERGY R\&D PROGRAM}

Since the inception of the Geothermal Program in 1971, the federal government and private industry have developed an extensive geothermal knowledge base, and industry has succeeded in establishing an industrial infrastructure capable of applying research results in the marketplace. This accumulation of technical information has provided a basis for identifying the critical technical barriers to cost-competitive geothermal power generation and for assessing long-term research options. Private sector cooperation in planning and prioritizing geothermal program elements contributes to the process by indicating desirable improvements in technology. This input is critical in a balanced, logical strategy for the Program that emphasizes highrisk research directed toward a significant long-term role for geothermal energy in the U.S. electric power economy, and which addresses carefully defined, near-term research to maintain industrial momentum in geothermal resource development.

In accordance with legislative mandates and policy guidance, the Geothermal Program sponsors high-risk, potentially high-payoff research and development in geothermal energy technology which will result in a technology base from which private enterprise can choose options for further development and competitive application in electric power markets.

The Geothermal Energy R\&D Program contains four categories that parallel the resource types: Hydrothermal, Geopressured, Hot Dry Rock, and Magma. These categories are further subdivided into tasks, projects, and activities.

\section{HYDROTHERMAL RESEARCH}

The Hydrothermal category embraces four interrelated research projects.

- The Industrialization project provides an opportunity for individual states to cooperatively assist in hydrothermal resource assessments and direct heat projects. FY1988 activities were carried over with FY 1987 funding.

- The Reservoir Technology project supports research that will improve geophysical interpretation and modeling techniques; improve injectivity and extend well 1 ife; and cooperatively fund industry research through the Geothermal Technology Organization. Notable FY 1988 achievements include:

- Reservoir Analysis

-- Performed analytical methods and interpretation of fluid inclusions in rocks of geothermal systems.

-- Performed geochemical data collection from Los Azufres, Mexico under international agreement.

-- Tested borehole electrical geophysical system for fracture detection. 


\section{- Brine Injection}

-- Analyzed results of heat transfer and chemical tracer diffusion through different rock types in laboratory tests of high-temperature fractured core flow model.

-- Developed a 3-dimensional flow model for injected brine in a geothermal reservoir.

-. Began testing vapor-phase tracers for injection monitoring.

-- Began conducting large-scale injection field test.

- Exploration Technology

-. Conducted a workshop and published final results of the cost-shared research.

- Geothermal Technology Organization

-- Began initial series of cost-shared research.

-- Solicited proposals for research projects and reviewed proposals.

- The Hard Rock Penetration project improves lost circulation methodologies and materials, rock penetration mechanics, and downhole instrumentation. This task also includes priority research, costshared with industry, through the auspices of the Geothermal Drilling Organization. Notable FY 1988 achievements include:

- Developed field procedures to measure characteristics of lost circulation zones.

- Tested high-temperature lost circulation materials.

- Evaluated fiber optic techniques for downhole measurements.

- Developed and tested second generation radar fracture mapping tool for higher temperatures.

- The Conversion Technology project strives to improve geofluid efficiencies in binary plants, reduce cooling water makeup requirements, develop advanced geothermal materials, and advance the understanding of the thermodynamic behavior of geothermal brines. Notable FY 1988 achievements include: 
- Heat Cycle

-- Tested condenser at the final attitude with the propane, isobutane family of working fluids.

-. Installed a two-dimensional nozzle and reaction turbine on the Heat Cycle Research Facility.

-. Began testing isobutane, hexane family of working fluids at the final condenser attitude -- conducted concurrently with the investigating of the condensation behavior of supersaturated turbine expansions.

- $\quad$ Advanced Brine Chemistry

-- Performed optimization experiments to examine the effectiveness of using mixed microorganisms to remove toxic elements from geothermal wastes.

-- Performed one-year laboratory and field evaluation of prototype construction materials containing encapsulated geothermal wastes.

- Materials Development

- Performed field tests on scaling factors, heat transfer coefficients, and corrosion rates for non-metallic heat exchanger tubing.

-- Began preliminary downhole test of advanced hightemperature cements under cooperative program with the Department of Scientific and Industrial Research, New Zeal and.

\section{GEOPRESSURED-GEOTHERHAL RESEARCH}

Geopressured-Geothermal category includes four projects.

- The Hell Operations project verifles the reliability of geopressuredgeothermal reservoirs through long-term research testing. Notable FY 1988 achievements include

- Shut-In the Gladys McCall well for long-term pressure build-up test.

- Started long-term flow test at Ṗleasant Bayou well. 
- The Geoscience and Engineering Support project involves the development of predictive models for reservoir performance. Notable FY 1988 achievements include:

- Performed detailed geologic investigation of Gladys McCall geology to determine reservoir geometry and fluid sources.

- The Energy Conversion project supports construction and operation of the Pleasant Bayou Hybrid Power System in Texas, which will use geopressured brines to produce electric power - the first plant of its kind in the world. Notable FY 1988 achievements include

- Initiated construction of EPRI experiment to verify the technology for electric energy conversion from a geopressured resource.

- The Management Support project provides general administration and technology exchange activities.

\section{HOT DRY ROCK RESEARCH}

The Hot Dry Rock category includes two projects.

- The Fenton Hill Operations project supports the second phase of the energy extraction system along with necessary ancillary activities at the Fenton Hill Hot Dry Rock site. Notable FY 1988 achievements include

- Began sidetracking of Well EE-2.

- Purchased and initiated installment of surface equipment for the Long Term Flow Test.

- The Scientific and Engineering Support project involves design and modification of tools and instrumentation, reservoir engineering work, and other technology support activities.

\section{MAGMA RESEARCH}

Magma research category is also divided into two projects.

- The Long Valley Operations project supports the drilling and engineering of a multiphased magma well at Long Valley caldera in California, including essential geoscience support activities. Notable FY 1988 achievements include:

- Performed medium-scale thermal fracturing experiments under dynamic solidification conditions. 
- The Laboratory and Engineering Support project encompasses research on drilling techniques, geochemistry and materials, and energy extraction. Notable Fy 1988 achievements include:

- Performed Phase 1 experimental studies of fluid flow and heat transfer in lab tests.

\section{BASIC GEOSCIENCES RESEARCH}

The Basic Geosciences Research activities of the Department of Energy's office of Energy Research include the conduct of basic research and development to study the geology, geophysics, geochemistry, and dynamics of thermal regions in the earth of long-term relevance to geothermal resources. Research and development in these areas should assist in resource recognition and evaluation activities. Three relevant areas of research include:

- Continental Scientific Drilling. The third scientific corehole in Valles Caldera was completed October 22, 1988, to a depth of $1761 \mathrm{~m}$. This hole penetrated the convective vapor and liquid cap of an active but slowly cooling hydrothermal system.

- Laboratory studies of thermochemistry, hydrogen spectroscopy, and degassing of silicate melts.

- Field geophysical studies of calderas and other regions of high thermal gradient.

\section{OTHER FEDERAL AGENCIES}

Other federal agencies, including the United States Geological Survey, Bureau of Mines, and Bureau of Reclamation within the Department of the Interior, have undertaken R\&D activities in the geosciences area. However, neither the Bureau of Mines' program to extract minerals from geothermal fiuids nor the Bureau of Reclamation's program to produce fresh water from saline geothermal fluids is active. 


\section{ENVIRONMENT}

The federal geothermal environmental activities focus on characterization of the environmental impacts from the development of geothermal energy sources and the development and evaluation of control methods to the mitigation or el imination of environmental concerns, including health issues. The coordination among the private sector, the research community, and federal and state government agencies on environmental matters has historically been provided by the IGCC's Environmental Controls Pane1. The Environmental Controls Panel successfully completed its effort in FY 1981 to refocus and integrate federal environmental research programs, with EPA, DOE, and DOI the principal participants in the environmental program. Along with other IGCC specialized panels, the Environmental Controls Panel is now inactive. It can be reactivated as appropriate to respond to specific concerns. The environmental program has included acquisition of baseline data; monitoring, and research related to air quality, surface and ground water quality, hydrological alternations, ecology, solid residuals, subsidence and seismicity, heal th effects, socioeconomic problems; and development and evaluation of environmental control technologies. The work since FY 1981 has concentrated on developing improved control methods and measuring actual impacts in the field.

FY 1988 achievements include:

- The hydrologic connection between geothermal targets outside of Lassen Volcanic National Park and the major geothermal system centered under the fumarolic areas within the park were evaluated by the NPS. These evaluations support park protection-related goals of the NPS. The characterization of geothermal resources in and around Yellowstone National Park was further based on information gained from studies at Lassen Volcanic National Park. On August 23, 1988, the final report of 1987 field studies conducted in Crater Lake was forwarded to the Senate Committee on Energy and Natural Resources and the House Committee on Interior and Insular Affairs. Work to define the thermal system at Crater Lake National Park continued. A small, manned submersible was used in the summer of 1988 to facilitate a more thorough mapping of the thermal features of the lake and to sample the venting fluids.

- The USGS monitored the flow rate, temperature, and chemical composition of springs in the Lassen geothermal area in northern California to establish the baseline measurements and natural variations against which the effects of future geothermal development may be assessed.

- The USGS continued characterizing the hydrothermal systems of Norris, Shoshone, and Upper and Lower Geyser basins through sampling and chemical analysis of thermal fluids. 
Also, in FY 1988, the EPA responded to section 3001(b)(2) of the 1980 amendments to the Resource Conservation and Recovery Act (RCRA) which require that, no later than six months after completion and submission of the Report to Congress on Crude 011 , Natural Gas, and Geothermal Energy Wastes required by Section $8002(\mathrm{~m})$ of the Act, the Administrator shall, after public hearings and opportunity for comment, determine either to promulgate regulations under RCRA or determine that such relations are unwarranted. The Administrator published his decision in the Federal Register on July 6,1988 accompanied by an explanation and a justification in which EPA concluded not to regulate wastes generated by the exploration and development of geothermal energy resources under RCRA Subtitle $C$. EPA believes that Subtitle $C$ control for these wastes is unwarranted because of the relatively low risk of these wastes and the presence of generally effective state and federal regulatory programs. 


\section{TECHNOLOGY TRANSFER}

Technology transfer is an integral part of all geothermal R\&D activities. Technology transfer of the products of federal R\&D is directed toward both technology producers (manufacturers and service firms) and technology consumers (geothermal field developers, drillers, electric utilities, etc.). The DOE Geothermal Energy R\&D Program emphasizes technology transfer approaches that encourage and allow market forces to obtain and utilize the technical information provided by the government. Earlier activities that employed direct financial incentives to promote the adoption of specific technologies have been discontinued. The annual DOE Geothermal Program Reviews and other meetings enhance the dissemination of information and coordination of R\&D efforts that are important components of technology transfer. In addition, the Geothermal Drilling Organization with more than 20 industry members, provides an efficient forum for both planning and disseminating relevant technology development.

The Geothermal Energy Research, Development and Demonstration Act of 1974 provided for the establishment of the Geothermal Loan Guaranty Program (GLGP) and the Geothermal Resource Development Fund. In March 1982, a Federal Register notice announced no further applications for new projects would be accepted, but all pending applications would be processed (10 CFR 790, March 1, 1982, Vol. 47, No. 40, p. 8555).

The objectives of the GLGP are to encourage the public and private sectors to accelerate the utilization of geothermal resources by minimizing lenders' financial risk; develop a financial service infrastructure to ultimately provide financing of geothermal projects without Federal assistance; and promote competition and encourage new entrance of firms into the geothermal marketplace. The GLGP has largely fulfilled its purpose, with eight guaranties and/or commitments issued since its inception, and FY 1989 activities will concentrate on program direction to monitor loans presently outstanding.

The 1974 Act authorized a total guaranty authority of $\$ 500$ million. The eight loan guaranties have a total face amount of $\$ 285.4$ million. Of these, one is outstanding ( $\$ 49.9 \mathrm{million})$, while three loans have been repaid and their guaranties released $(\$ 50.8$ million face amount but only $\$ 49.5$ million actualiy disbursed). The remaining four loans (with a total face amount of $\$ 184.6$ million but actual disbursements of only $\$ 38.7$ million) have defaulted and been paid off by DOE under its guaranty obitgations.

Financial and economic incentives for private sector development are also provided by other federal agencies. The Departments of Commerce and Housing and Urban Development offer financing opportunities for geothermal development in their grant programs. Communities may choose to utilize their HUD Community Development Block Grant (CDBG) funds for this purpose, and may request Urban Development Action Grants (UDAG's) provided that private sector leveraging and other requirements are met. 
TABLE 3

GEOTHERMAL RESOURCES DEVELOPMENT FUND AND GUARANTY AUTHORITY 1

\section{FY 1988}

FUND(\$)

AUTHORITY (\$)

a) Program direction

b) Carried over from FY 1987

c) Guaranty fees collected

d) Total available

e) Paid on defaults

f) Administrative expenses 3

g) Total outlays

h) Balance at end of FY 1988 (b through g)

i) Guaranty authority

j) Authority committed to date ( 8 projects)

k) Authority avallable

1) Total paid off on defaults

m) Guarantied loans fully repaid by borrower
\$ 72,000

$11,509,870$

505,914

$12,015,784$

$6,415,269$

564,420

$6,979,689$

$5,036,095^{\circ}$

$\$ 500,000,000$ $285,398,000$ $214,602,000$

$39,915,269$

$49,555,600$

(1) This financial information is included in the Thirteenth Annual Report to satisfy the requirements of Public Law 93-410, Section 204.

(2) Includes $\$ 72,527$ received as rental payments on Oregon Trail Mushroom leases that were taken as collateral upon OTM default.

(3) Contractor, consultant, and personnel costs necessary to assist in evaluating technological, geophysical, financial, marketing, management, and legal data submitted with guaranty applications and to assist in monitoring guarantied projects. 


\section{FEDERAL USE OF GEOTHERMAL ENERGY}

Where economically appropriate, the federal government has been involved in the utilization of geothermal resources. In particular, the Department of Defense has been active in the development and use of geothermal energy at several military installations.

On July 15, 1987, at Naval Weapons Center, China Lake, California, Navy Geothermal P1ant Number One, Unit Number One, began delivering power to the public utility grid. Unit One is rated at 25 MHe capacity and has been running steadily at 34 MWe. Naval Weapons Center's peak power demand is 20 MWe. Plant Number One, Units Two and Three, are under construction. Completion date is set for December 1988. Units One through Three will bring the Navy's operating capacity to. 80 MWe. Permitting is underway for an additional 80 MWe with planned Units Four through Six, with an expected start-up in late 1989. Additional capacity is planned so that the total on-line power at the site will be brought to $230 \mathrm{MWe}$. The California Energy Company, Inc. and Mission Power (a subsidiary of Southern California Edison) are the plant and field developers.

The Naval Weapons Center released one technical publication during 1988. This report, entitled Reconnaissance Study of Coso Volcanic Field, California, and Pickel Meadows, California, (NWC TP 6909), documents a geochemical and geophysical reconnaissance study performed in 1986 by the U.S. Geological Survey for the Naval Weapons Center. 


\section{PRIVATE SECTOR USE OF GEOTHERMAL ENERGY}

Geothermal energy has been used for space and district heating in the United States since the late $1800^{\prime} \mathrm{s}$. Current uses include agriculture and aquacultural applications, space/district heating, and industrial applications. Currently, direct utllization of geothermal energy is less than 0.1 quads/year. Most of the direct-utilization of geothermal energy is concentrated in California, Idaho, Nevada, New Mexico, Oregon, and South Dakota. Directutilization is expected to grow significantly over the next few years, with expansion projected in industrial applications and district heating systems.

The commercial production of electricity from geothermal energy first occurred in the United States in 1960 at The Geysers in California. Since that time, numerous facilities have been constructed. Since March 1980, when qualification of small power and cogeneration facilities under 18 CFR 292 began, through the end of FY 1988, the Federal Energy Regulatory Commission has certified or received notices of qualifying status - those plants less than 80 MWe - for 2,212 MWe of non-utility geothermal electric generating capacity. During FY 1988, several prospective geothermal electric generating facilities were certified by the commission to be qualifying facilities, or filed notices of qualifying status, as shown in Table 4. 
TABLE 4

QUALIFICATION STATUS OF NON-UTILITY

GEOTHERMAL GEMERATING CAPACITY

Applicant Name

(Docket No.)

COSO ENERGY DEVELOPERS

(QF86-590-001)

CALIFORNIA ENERGY COMPANY

(QF86-591-001)

GEO EAST MESA NO. 2 INC.

(QF88-202-000)

GEO EAST MESA LIMITED PARTN.

(QF88-202-001)

GEO EAST MESA NO. 2 INC.

(QF88-203-000)

GEO EAST MESA LIMITED PARTN. (QF88-203-001)

CEJA CORPORATION

(QF88-316-000)

ORMESA IE

(QF88-381-000)

STILLWATER GEOTHERMAL 2

(QF88-523-000)

RYE PATCH GEOTHERMAL 2

(QF88-524-000)

EMPIRE GEOTHERMAL 2

(QF88-525-000)

STEAMBOAT GEOTHERMAL 4

(QF88-526-000)

STEAMBOAT GEOTHERMAL 2

(QF88-527-000)

STEAMBOAT GEOTHERMAL 3

(QF88-528-000)

STILLWATER GEOTHERMAL 4

(QF88-529-000)

RYE PATCH GEOTHERMAL 1

(QF88-530-000)

STILLWATER GEOTHERMAL 3

(QF88-531-000)

ORMESA IH

(QF88-532-000)

ANADARKO PETROLEUM CORPORATION

(QF88-536-000)

1-A ENTERPRISES

(QF88-538-000)

EATON OPERATING COMPANY, INC.

(QF88-539-000)
Location

CA

9.1

CA

0.1

CA

37.0

CA

18.5

CA

37.0

CA

18.5

NV

5.0

CA

10.0

NV

10.0

NV

10.0

NV

10.0

NV

10.0

NV

10.0

NV

10.0

NV

25.0

NV

10.0

NV

10.0

CA

12.8

OR

12.0

NA

1.5

TX

1.05

175.35 